\title{
Analysis of Scalp Wound Infections Among Craniocerebral Trauma Patients Following the 2008 Wenchuan Earthquake
}

\author{
Wenchuan'da 2008 Yilundaki Depremde Meydana Gelen Kranioserebral \\ Travmalı Hastalar Arasinda Saçlı Derisinde Yara Enfeksiyonu Olan \\ Olgularn Incelenmesi
}

\author{
Jiagang LIU, Lu MA, Chao YOU \\ West China Hospital, Sichuan University, Department of Neurosurgery, Chengdu, China
}

Correspondence address: Chao YOU / E-mail: brainspine2010@163.com

\begin{abstract}
AIM: To explore the causes of scalp wound infection, pathogen distribution, characteristics of antimicrobial susceptibility and therapeutic measures following craniocerebral trauma caused by the 2008 Wenchuan earthquake.

MATERIAL and METHODS: We retrospectively analyzed the microbiology records of patients admitted with craniocerebral trauma to the Department of Neurosurgery, West China Hospital, Sichuan University. Scalp wound infections following craniocerebral trauma were caused by the Wenchuan earthquake.

RESULTS: A total of 82 patients suffered from scalp trauma in this study, including $52.4 \%$ cases (43/82) with wound infections, mostly accompanied by severe foreign body contamination, for which the time of first debridement was significantly delayed. There were 59 strains of infectious pathogenic bacteria. Gram-positive bacteria were the most common organisms found (64.4\%), including strains of Staphylococcus aureus $(26 / 59,44.1 \%)$ and strains of Staphylococcus epidermidis $(12 / 59,20.3 \%)$. Gram-negative bacteria accounted for $35.6 \%$ of samples: $22.0 \%$ (13/59) were strains of Enterobacter cloacae; 5.1\% (3/59) were strains of Klebsiella pneumoniae; and 8.5\% (5/59) were strains of Serratia rubidaea.

CONCLUSION: The rate of scalp wound infections following earthquake-induced craniocerebral trauma, which was dominated by Grampositive Staphylococcus aureus infection, has been markedly elevated in recent years. Early debridement and suturing, nutritional support and application of sensitive antibiotics can augment the therapeutic effect.
\end{abstract}

KEYWORDS: Earthquake, Craniocerebral trauma, Scalp laceration, İnfection, Bacterial culture

öz

AMAÇ: Wenchuan'da 2008 yılındaki depremde meydana gelen kranioserebral travmalardaki skalp yara infeksiyonlarının sebeplerini, patojen dağılımını, antimikrobial duyarlıığının özelliklerini ve tedavi önlemlerini araştırmak.

YÖNTEM ve GEREÇ: Wenchuan depremi sırasında Sichuan Üniversitesi Batı Çin Hastanesi Beyin cerrahisi bölümüne kranioserebral travma nedeni ile kabul edilen hastaların mikrobiyolojik kayıtları retrospektif olarak incelenmiştir.

BULGULAR: Skalp yaralanması olan toplam 82 hasta bu çalışmaya dahil edilmiştir. Olguların \% 52,4 'ünde (43/82) yara infeksiyonu vardı; bu hastalarda ciddi şekilde yabancı cisim kontaminasyonu vardı ve bu olgularda yapılan ilk depritmanlar oldukca geç bir dönemde yapılmıştı. Değişik suşlarda 59 infeksiyöz patojenik bakteri bulundu. Gram pozitif bakteriler \%58,4 ile en sık görülen organizmaydı, bunlar içinde; Stafilokokkus Aureus (26/59, \%44,1), Stafilokokkus Epidermidis (12/59, \%20.3), gram negatif bakteriler \% 35,6 olguda görüldü, bunlar içinde Enterobakter Kloasae: \%22,0 (13/59), Klebsiella pnömoni \%1 (3/59) ve Serratia rubidaea \%8,5 (5/59) oranlarında bulundu.

SONUÇ: Deprem sırasında oluşan kranioserebral travmalardaki skalp infeksiyonlarında Gram pozitif Stafilokkokus aureus sık olarak görülmektedir; bu infeksiyonun sıklığı son yıllarda bariz olarak artmaktadır. Erken dönmede yara debridmanı ve suture edilmesi yanı sıra beslenme desteği ve uygun antibiyotik tedavisinin uygulanması tedavi etkinliğini artırmaktadır.

ANAHTAR SÖZCÜKLER: Deprem, Kranioserebral travma, Skalp yırtılması, Enfeksiyon, Bakteri kültürü 


\section{INTRODUCTION}

At 2:28 pm on May 12, 2008, a powerful earthquake, magnitude 8.0 on the Richter Scale, jolted Wenchuan County in southwest China's Sichuan Province (hereinafter referred to as the "Wenchuan" earthquake). The earthquake led to serious casualties and economic losses. According to the official reports, the earthquake disaster caused more than $3,744,171$ injuries and 69,185 deaths, and 18,467 people were considered missing. As of June $12^{\text {th }}$, a total of 2,702 people wounded in the earthquake were admitted to West China Hospital (4,300-bed capacity), including 182 treated in the Department of Neurosurgery for craniocerebral trauma. Scalp wounds are rarely vulnerable to infection, due to the abundant blood supply. However, at our hospital, scalp wound infections were frequently seen among people wounded in the earthquake. The microbiology of scalp wound infections differs from that of routine wound infections in ordinary patients. The objective of our study was to survey the frequency of infection due to different pathogenic bacteria and to elucidate the associated antibiotic sensitivity patterns. We describe the characteristics of such infections in order to improve the level of comprehensive treatment available to the wounded.

\section{MATERIAL and METHODS}

General data: A total of 182 wounded people with craniocerebral trauma caused by the "Wenchuan" earthquake were admitted to the Department of Neurosurgery of our hospital, including 82 cases of scalp injury (male: 27; female: 16 ), aged 2 to 83 years with an average age of 47.4 years, 77 cases of scalp laceration and 5 cases of scalp avulsion. All 82 subjects underwent bacterial culture and drug susceptibility testing of wound secretions.

Treatment: After admission, all of the patients were uniformly injected with tetanus immunoglobulin. They also underwent head CT and routine systemic physical examination. Patients with intracranial hypertension caused by severe craniocerebral trauma, such as intracranial hematoma or cerebral contusion and laceration, were treated with active surgical procedures. Patients with acute renal dysfunction accompanied by either thoracic or abdominal injury or limb fractures were treated appropriately. If any head injury was found, wound surface secretion culture, hair shaving and wound debridement were conducted to remove foreign bodies and necrotic tissues; dressings were changed daily. Broad-spectrum antibiotics such as ceftriaxone ( $2.0 \mathrm{~g}$ bid) were injected intravenously. Treatment was then revised to include sensitive antibiotics based on the results of the culture and drug susceptibility testing.

$A X^{2}$ test was used to calculate the differences in infection rates for pathogenic bacteria from scalp wounds debrided within 3 days as compared to those debrided after more than 3 days. A P-value of $\leq 0.05$ was considered statistically significant.

\section{RESULTS}

The results suggested that $47.6 \%(39 / 82)$ of cases had no infection and $52.4 \%$ (43/82) had wound infections, including $19.5 \%(16 / 82)$ with mixed infections; in total, 59 pathogens were detected. Among these 43 infected cases, 42 finally healed from wound infections, with the average hospital stay of 32 days. One patient died of central respiratory and circulatory failure induced by primary brain stem injury. The time of first debridement significantly affected the ratio of scalp wound infections. In the 43 cases with scalp infections, $86.1 \%$ (37/43) received the debridement therapy $>3$ days after trauma, while in the cases with scalp trauma but no infection, $79.5 \%(31 / 39)$ received debridement and suturing within 3 days post trauma (Figure 1).

Gram-positive bacteria-induced infections (38/59,64.4\%) were observed frequently in this study: Staphylococcus aureus, 44.1\% (26/59; 23 MSSA and 3 MRSA) and Staphylococcus epidermidis, 20.3\% (12/59). Gram-negative bacteria caused $35.6 \%(21 / 59)$ of infections, predominantly Enterobacter

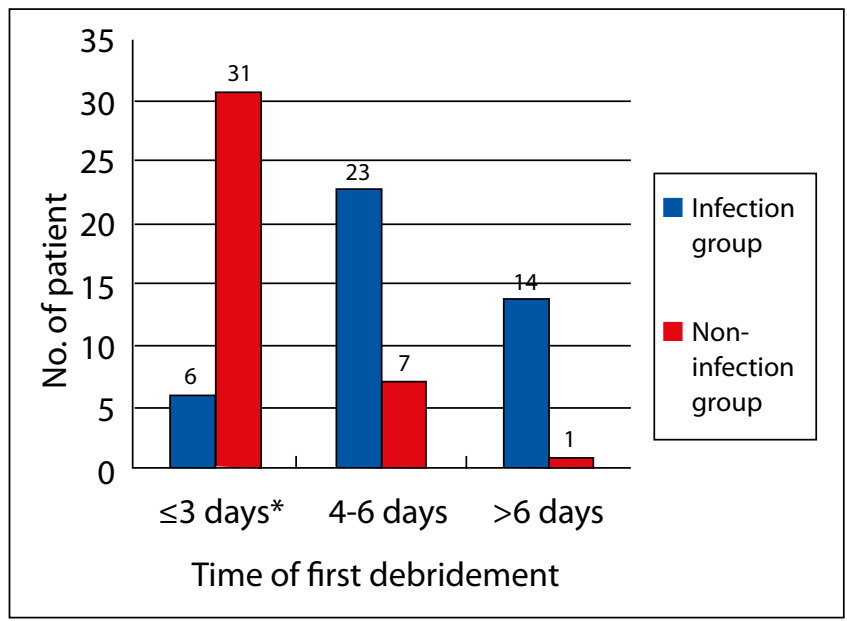

Figure 1: Comparison between the time of the first debridement for patients with scalp trauma in the two groups ${ }^{*} \mathrm{P}<0.05$ compared with scalp wounds debrided exceeding 3 days.

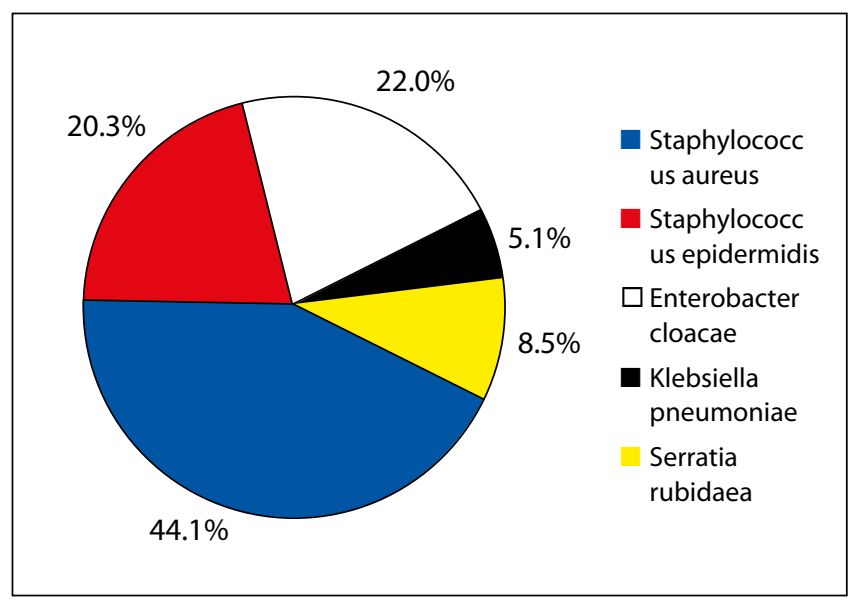

Figure 2: Pathogens scale map for scalp wound infections. 
cloacae $(22.0 \%, 13 / 59)$, followed by Serratia rubidaea $(8.5 \%$, $5 / 59)$ and Klebsiella pneumoniae $(5.1 \%, 3 / 59)$. Fungal or anaerobic infections were not detected in this study (see Figure 2).

Results for the drug susceptibility test showed that grampositive bacteria were absolutely sensitive to vancomycin without drug-resistant strains, followed by imipenem and linezolid, but fully resistant to penicillin and ampicillin (see Table I). Gram-negative bacteria were most sensitive to imipenem and resistant to other drugs in varying degrees. (Because the cardinal number is too small, there is no list to analyze the resistance rate).

\section{Outcomes}

Patient outcomes were assessed using the Glasgow Outcome Scale. Of the 82 patients included in this study, 1.2\% (1/82) died due to primary brain stem injury during the hospital stay, while $98.8 \%$ (81/82) survived with positive outcomes. Followup at one year revealed that the scalp laceration was fully healed, and there was no sign of infection.

\section{DISCUSSION}

An earthquake is one of the most devastating natural disasters. Transportation interruptions, destruction of a large number of medical and health facilities, shortages of water, electricity and medical supplies and numerous wounded people combined with insufficient medical staff all created great obstacles with respect to rescue of the wounded $(1,7,9,18)$. In particular, hunger, great psychic trauma and weakened immunity, in addition to a great deal of direct contact between a large number of open wounds with pollutants such as rubble and soil, all resulted in the invasion of a variety of pathogens into the human body, leading to regional or systemic infections following trauma $(2,5,16)$.

The internationally recognized critical period for medical aid following an earthquake is 72 hours. This period of time reflects the physiological and psychological limits that people wounded in the earthquake can bear. If these people can be effectively treated, they may recover rapidly. Among the patients with scalp wound infections in our study, $86.1 \%$ received debridement $>3$ days after trauma, while $79.5 \%$ of the non-infection group received debridement and suturing within 3 days after trauma. The infection rate of the two groups was significant $(P<0.05)$. This result shows that the early intervention therapy could obviously reduce the frequency of scalp infections. Mulvey et al. (11) reported that the most common types of injury associated with the 2005 Kashmir earthquake were superficial lacerations (64.9\%) and fractures (22.2\%). During the first 72 hours, all wounds were thoroughly washed and disinfected. All of the patients received antibiotics such as ceftriaxone and amoxicillin. The treatment results were good, and there was no sepsis or death at follow-up. Only $14.8 \%$ had clinically relevant infections requiring surgical debridement and further antibiotic therapy. Therefore, the first 72 hours represents a critical period for earthquake rescue. Bulut (3) reported
Table I: Drug Resistance Rate of Gram-Positive Bacteria (\%)

\begin{tabular}{|l|c|c|}
\hline Antibiotic & $\begin{array}{c}\text { Staphylococcus } \\
\text { aureus }\end{array}$ & $\begin{array}{c}\text { Staphylococcus } \\
\text { epidermidis }\end{array}$ \\
\hline Vancomycin & 0.00 & 0.00 \\
Cephazoline & 50 & 33.3 \\
Ceftriaxone & 15.4 & 25 \\
\hline Linezolid & 7.7 & 8.3 \\
\hline Imipenem & 15.4 & 8.3 \\
\hline Ampicillin & 100 & 100 \\
Penicillin & 100 & 100 \\
\hline Rifampicin & 30.8 & 16.6 \\
Cotrimoxazole & 53.8 & 33.3 \\
Gentamicin & 38.4 & 25
\end{tabular}

that after the 1999 Marmara earthquake in Turkey, 42\% of wounded people admitted to their hospital were sent into the hospital within the first $24 \mathrm{~h}$. Chen (4) reported that after the Chi-Chi earthquake in Taiwan, $66.2 \%$ of wounded people were admitted to their hospital in the first $24 \mathrm{~h}$. According to evidence-based statistics in our West China Hospital (17), the number of wounded people admitted to our hospital within the first three days accounted for $27.5 \%$ of all wounded people. There is no doubt that the massive Wenchuan earthquake epicenter was located in the distant mountain areas of west China. The intensity of the earthquake and its unprecedented destructive power resulted in great difficulty with regard to the rescue and the transportation of the wounded. During the first two days after earthquake, helicopters from the Chinese Army were the only available transportation. These facts highlight the importance of saving wounded people in the 72 hours period after the disaster.

The human scalp is rich in blood circulation and is powerful in immunity. Thus, scalp wound infections rarely occur in the natural course of events. However, the open wounds of people injured in an earthquake are continually polluted by relics of destroyed buildings and by soil; blood loss from the wounds and hunger may lead to anemia and hypoproteinemia. Due to these factors and the increased entrapment time, the rate of scalp wound infection is significantly elevated. In this study, infections occurred in up to $52.4 \%$ of scalp wounds. Previous studies have not yet reported on the rate of scalp wound infections among people wounded during an earthquake.

Our study focused on wound infections prior to hospitalization; all of the secretion or pus samples were tested at the time of admission. In our study, infections caused by Gram-positive bacteria were much more prevalent (64.4\%) than those caused by Gram-negative pathogenic bacteria (35.6\%). Grampositive bacteria included Staphylococcus aureus (44.1\%) and Staphylococcus epidermidis (20.3\%); Gram-negative bacteria included Enterobacter cloacae (22\%), followed by Serratia rubidaea $(8 \%)$ and Klebsiella pneumoniae $(5 \%)$. The results of bacteriological identification and antibiotic susceptibility 
were quite different from those of studies of hospitalacquired-infections (HAls) among earthquake victims. A $\mathrm{HAl}$ was defined as an infection that had its onset during hospitalization but was not present at the time of admission. In other recent reports on HAls, Gram-negative bacteria were most frequently isolated from earthquake victims, with numbers ranging from $71.3 \%$ to $89 \%(3,6,12,13,16$,$) . Kiani$ et al. (8) showed that Pseudomonas aeruginosa (30.5\%), Enterobacter spp. (22.3\%) and Acinetobacter spp. (15.8\%) were the most common isolates from patients following the 2005 Pakistan earthquake, and most of these were multi-drug resistant. Oncul et al. (12) analyzed the bacterial spectrum for infections among injured patients hospitalized following the earthquake. The results showed that $18.6 \%$ of these hospitalized patients suffered from nosocomial infections. Among these patients, the majority suffered from wound infections (46.5\%), which were detected through bacterial culture of pathogenic bacteria including Acinetobacter baumannii (31.2\%), Staphylococcus aureus (18.7\%), Pseudomonas aeruginosa (14.6\%), E. coli $(12.5 \%)$, Klebsiella pneumoniae (12.5\%), Stenotrophomonas maltophilia (4.2\%) and Pseudomonas (6.3\%).

Most of the Staphylococcus aureus in our study were methicillin-sensitive Staphylococcus aureus (MSSA 23/26), with onlythree samples of methicillin-resistant Staphylococcus aureus (MRSA 3/26). These results indicated that in the remote Chinese mountains, MSSA was the most common identifiable cause of wound infection following earthquake. Moran et al. (10) reported that MRSA has emerged as the leading cause of skin and soft-tissue infections in several metropolitan areas across the United States. Furthermore, MRSA was found to be a major health-care-associated pathogen after the tsunami in 2004 and during the hurricane Katrina disaster $(14,15)$. These results indicate that the causes of wound infections differed between remote areas and big cities and that the prevalence of MRSA was increased among community-associated infections and hospital-acquired infections.

Optimal empirical antimicrobial therapy for scalp wound infection following an earthquake has not been established. As $\beta$-lactamase-positive strains, all the MSSA and MRSA in our study were $100 \%$ resistant to penicillin and ampicillin, but were absolutely sensitive to vancomycin. We did not choose vancomycin because of its relatively severe renal toxicity, and because quite a few of the earthquake victims are vulnerable to crush syndrome and acute renal failure. Most of the patients in our study were treated with ceftriaxone because it has relatively low renal toxicity and high penetrability to softtissue, meninges, eyes and inner ears. In our study, we found no obvious association between patients' outcomes and susceptibility of the pathogenic bacteria to antibiotics. Most scalp wounds can be cured with adequate debridement and drainage. The use of antimicrobial agents aims to prevent the evolution of regional infection to a systemic infection such as septicemia.
Infections caused by Gram-negative bacteria were relatively rare (35.6\%). Gram-negative bacteria are mostly conditioned pathogens, which are sensitive to a variety of antibiotics and do not exhibit special drug-resistant phenomena. In our study, no anaerobic infections such as tetanus or gas gangrene were found, which might be related to comparatively superficial scalp wounds and rich blood circulation, which are not liable to result in an oxygen-deficient microenvironment. If the wounded are injected with tetanus immunoglobulin immediately after admission, the prophylaxis should certainly be effective.

In conclusion, the rate of primary earthquake-induced scalp wound infections is comparatively high, with pathogenic bacteria dominated by Gram-positive Staphylococcus aureus. Early debridement, application of sensitive antibiotics and nutritional support may have satisfactory results.

\section{REFERENCES}

1. Bilham R: Lessons from the Haiti earthquake. Nature 463(7283): 878-879, 2010

2. Bowler PG, Duerden BI, Armstrong DG: Wound microbiology and associated approaches to wound management. Clin Microbiol Rev 14: 244-269, 2001

3. Bulut M, Fedakar R, Akkose S, Akgoz S, Ozguc H, Tokyay R: Medical experience of a university hospital in Turkey after the 1999 Marmara earthquake. Emerg Med J 22:494-498, 2005

4. Chen WK, Cheng YC, Ng KC, Hung JJ, Chuang CM: Were there enough physicians in an emergency department in the affected area after a major earthquake? An analysis of the Taiwan Chi-Chi earthquake in 1999. Ann Emerg Med 38: 556-561, 2001

5. Geertruid MH, Dylan WL, Luke PH, Andy IM: Wound infections in repatriated survivors of the tsunami disaster. Wounds 18 : 92-100, 2006

6. Kang M, Xie Y, Mintao C, Chen Z, Chen H, Fan H, Chen W, Guo X: Antimicrobial susceptibility of clinical isolates from earthquake victims in Wenchuan. Clin Microbiol Infect 15: 87-92, 2009

7. Keven K, Ates K, Sever MS, Yenicesu M, Canbakan B, Arinsoy T, Ozdemir N, Duranay M, Altun B, Erek E: Infections complications after mass disasters: The Marmara earthquake experience. Scand J Infect Dis 35:110, 2003

8. Kiani QH, Amir M, Ghazanfar MA, Iqbal M: Microbiology of wound infections among hospitalised patients following the 2005 Pakistan earthquake. J Hosp Infect 73: 71-78, 2009

9. Kuwagata $Y$, Oda J, Tanaka H, Iwai A, Matsuoka T, Takaoka M, Kishi M, Morimoto F, Ishikawa K, Mizushima Y, Nakata Y, Yamamura H, Hiraide A, Shimazu T, Yoshioka T: Analysis of 2702 traumatized patients in the 1995 Hanshin-Awaji earthquake. J Trauma 43: 427-432, 1997

10. Moran GJ, Krishnadasan A, Gorwitz RJ, Fosheim GE, McDougal LK, Carey RB, Talan DA: Methicillin-Resistant S. aureus infections among patients in the Emergency Department. $\mathrm{N}$ Engl J Med 355: 666-674, 2006 
11. Mulvey JM, Awan SU, Qadri AA, Maqsood MA: Profile of injuries arising from the 2005 Kashmir earthquake: The first 72 hours. Injury 39(5):554-560, 2008

12. Oncul O, Keskin O, Acar HV, Küçükardali Y, Evrenkaya R, Atasoyu EM, Top C, Nalbant S, Ozkan S, Emekdaş G, Cavuşlu S, Us MH, Pahsa A, Gökben M: Hospital-acquired infections following the 1999 Marmara earthquake. J Hosp Infect 51: 47-51, 2002

13. Tao C, Kang M, Chen Z, Xie Y, Fan H, Qin L, Ma Y: Microbiologic study of the pathogens isolated from wound culture among Wenchuan earthquake survivors. Diagn Microbiol Infect Dis 63: 268-270, 2009

14. Todd B: Infection control and Hurricane Katrina. What nurses can learn in the aftermath of the disaster. Am J Nurs 106: 29-31, 2006
15. Uckay I, Sax H, Harbarth S, Bernard L, Pittet D: Multi-resistant infections in repatriated patients after natural disasters: Lessons learned from the 2004 tsunami for hospital infection control. J Hosp Infect 68: 1-8, 2008

16. Wang T, Li D, Xie Y, Kang M, Chen Z, Chen H, Fan H, Wang L, Tao $C$ : The microbiological characteristics of patients with crush syndrome after the Wenchuan earthquake. Scand J Infect Dis 42(6-7): 479-483, 2010

17. Xie J, Du L, Xia T, YP Li: Analysis of the traumatic condition and death for 1861 hospitalized and dead people in West China Hospital affiliated to Sichuan University after Wenchuan earthquake. Chinese Journal of Evidence-Based Medicine 8: 591-596, 2008

18. Zhang $L$, Li $H$, Janis $R$, R Ursano: The injury profile after the 2008 earthquake in China. Injury 40: 84-86, 2009 